\title{
Dimethyl fumarate-induced lymphopenia in MS due to differential T-cell subset apoptosis
}

\section{OPEN}

Mahtab Ghadiri, MBBS, FRACP

Ayman Rezk, BSc

Rui Li, MD, PhD

Ashley Evans, $\mathrm{PhD}$

Felix Luessi, MD

Frauke Zipp, MD

Paul S. Giacomini, MD, FRCPC

Jack Antel, MD, FRCPC

Amit Bar-Or, MD,

FRCPC

Correspondence to

Dr. Bar-Or:

amit.bar-or@uphs.upenn.edu

Supplemental data at Neurology.org/nn

\section{ABSTRACT}

Objective: To examine the mechanism underlying the preferential CD8+ vs CD4+ ${ }^{+}$-cell lymphopenia induced by dimethyl fumarate (DMF) treatment of MS.

Methods: Total lymphocyte counts and comprehensive T-cell subset analyses were performed in high-quality samples obtained from patients with MS prior to and serially following DMF treatment initiation. Random coefficient mixed-effects analysis was used to model the trajectory of T-cell subset losses in vivo. Survival and apoptosis of distinct T-cell subsets were assessed following in vitro exposure to DMF.

Results: Best-fit modeling indicated that the DMF-induced preferential reductions in $\mathrm{CD}^{+}$vs $\mathrm{CD}^{+}{ }^{+} \mathrm{T}$-cell counts nonetheless followed similar depletion kinetics, suggesting a similar rather than distinct mechanism involved in losses of both the $\mathrm{CD} 8^{+}$and $\mathrm{CD} 4^{+} \mathrm{T}$ cells. In vitro, DMF exposure resulted in dose-dependent reductions in T-cell survival, which were found to reflect apoptotic cell death. This DMF-induced apoptosis was greater for $\mathrm{CD}^{+}{ }^{+} \mathrm{vs} \mathrm{CD}_{4}{ }^{+}$, as well as for memory vs naive, and conventional vs regulatory T-cell subsets, a pattern which mirrored preferential T-cell subset losses that we observed during in vivo treatment of patients.

Conclusions: Differential apoptosis mediated by DMF may underlie the preferential lymphopenia of distinct T-cell subsets, including $\mathrm{CD}^{+}$and memory T-cell subsets, seen in treated patients with MS. This differential susceptibility of distinct T-cell subsets to DMF-induced apoptosis may contribute to both the safety and efficacy profiles of DMF in patients with MS. Neurol Neuroimmunol Neuroinflamm 2017;4:e340; doi: 10.1212/NXI.0000000000000340

\section{GLOSSARY}

DMF = dimethyl fumarate; EDSS = Expanded Disability Status Score; FAE = fumaric acid ester; $\mathbf{H C}=$ healthy control; MMF = monomethyl fumarate; PBMC = peripheral blood mononuclear cells; PI = propidium iodide; $\mathbf{P M L}=$ progressive multifocal leukoencephalopathy; RM ANOVA = repeated measures analysis of variance; RRMS = relapsing-remitting MS; $\mathbf{R T E}=$ recent thymic emigrant; $\mathbf{S O P}=$ standard operating procedure; $\mathbf{T L C}=$ total lymphocyte count

Dimethyl fumarate (DMF; Tecfidera, Biogen, Weston, MA) is an oral fumaric acid ester (FAE) which has been shown to reduce clinical relapses and MRI measures of inflammatory disease activity in relapsing-remitting MS (RRMS). ${ }^{1,2}$ The mechanism/s underlying the ability of DMF to reduce inflammatory disease in MS remains incompletely elucidated, although both cytoprotective and immunomodulatory actions of DMF and its major metabolite, monomethyl fumarate (MMF), have been postulated ${ }^{3-11}$ (reviewed in references 12,13 ).

Given its cytoprotective potential, it was somewhat surprising to observe that DMF treatment in the pivotal phase III trials resulted in approximately $30 \%$ decreases in total lymphocyte counts (TLCs), with $5 \%$ of patients experiencing grade 3 lymphopenia (TLC $<0.5 \times 10^{9}$ cells/L). ${ }^{1,2}$ Postmarketing studies also reported lymphopenia in up to $50 \%$ of patients, noting a preferential reduction of $\mathrm{CD}^{+}$vs $\mathrm{CD}^{+}$T-cell counts. ${ }^{14-16}$ Rare cases of progressive multifocal

\footnotetext{
From the Montreal Neurological Institute (M.G., A.R., R.L., P.S.G., J.A., A.B.-O.), McGill University, Montreal, QC, Canada; Brain and Mind Centre (M.G.), University of Sydney, NSW, Australia; Institute of Actuaries of Australia (A.E.); Department of Neurology (F.L., F.Z.), University Medical Center Mainz, Germany; and Department of Neurology (A.R., R.L., A.B.-O.), Perelman School of Medicine, University of Pennsylvania, Philadelphia.

Funding information and disclosures are provided at the end of the article. Go to Neurology.org/nn for full disclosure forms. The Article Processing Charge was paid by the authors.

This is an open access article distributed under the terms of the Creative Commons Attribution-NonCommercial-NoDerivatives License 4.0 (CC BY-NC-ND), which permits downloading and sharing the work provided it is properly cited. The work cannot be changed in any way or used commercially without permission from the journal.
} 
leukoencephalopathy (PML) have occurred in patients taking $\mathrm{DMF}^{17,18}$ and have been linked with, but not restricted to, sustained severe lymphopenia. ${ }^{18,19}$

Mechanisms underlying DMF-induced lyphopenia remain incompletely elucidated. Important questions include whether distinct mechanisms explain differential $\mathrm{CD}^{+}$vs $\mathrm{CD}^{+}{ }^{+} \mathrm{T}$-cell subset losses, and how cell subsets with specific immunologic roles are affected by DMF. A greater understanding of these issues will aid safer treatment decisions and monitoring of DMF use in patients. Here, using a combination of in vivo and in vitro approaches, we investigated the mechanism underlying the preferential losses of $\mathrm{CD}^{+}$vs $\mathrm{CD}^{+} \mathrm{T}$ cells induced by DMF treatment in patients with MS.

METHODS Participants and study design. Thirteen patients ( 11 women and 2 men) with RRMS and a mean age of 41 years (range 20-60 years) were prospectively followed at a single center in Montreal, Canada, prior to and following treatment initiation with DMF. Patients were assessed every 3 months with clinical review, physical examination and Expanded Disability Status Score (EDSS), and blood procurement with isolation of peripheral blood mononuclear cells (PBMC) when possible. At study entry, patients had an average EDSS of 2.5 (range 1.0-4.0), preceding annualized relapse rate of $0.8(0-2)$ and disease duration of 9.6 years (range 1-27 years). Eleven of the 13 patients had previously been treated with either interferon or glatiramer acetate, 1 had received a single dose of ofatumumab 18 months prior to recruitment, and 1 was treatment naive. Ten healthy controls were recruited for in vitro studies.

Blood sample processing and cell culture. Complete blood counts including TLC were performed by a certified clinical laboratory. T-cell subset absolute counts were estimated using the clinical laboratory TLC results and flow cytometry gating of individual subsets within the total lymphocyte populations. Highquality PBMC were separated by density centrifugation using Ficoll (GE Healthcare, Little Chalfont, UK), and a portion was cryopreserved using strict standard operating procedures for all phases of sample procurement, processing, freezing, storage, and subsequent thawing. Where indicated, magnetic bead sorting (Miltenyi Biotec, Bergisch Gladbach, Germany) was used to negatively select $\mathrm{CD}^{+} \mathrm{T}$ cells from freshly isolated or thawed PBMC with purities of typically $>94 \%$ as confirmed by flow cytometry. For measurement of FAE-induced apoptosis, freshly isolated PBMC and T cells were cultured in serum-free $\mathrm{X}$-vivo 10 medium (Lonza, Basel, Switzerland) at $3 \times 10^{5}$ cells/ well in 24-well plates for 3 days. Cell cultures were treated with medium alone, vehicle (dimethyl sulfoxide [DMSO]), MMF, or DMF (Sigma-Aldrich, Oakville, ON, Canada). MMF and DMF were added to individual wells across a concentration range $(10,25$, or $50 \mu \mathrm{M})$, with DMSO control added at the highest $(50 \mu \mathrm{M})$ equivalent concentration. Given the short half-life of DMF, ${ }^{20}$ a second identical dose of DMF, MMF, or vehicle was added to each well after a 60-minute incubation. For dexamethasoneinduced apoptosis assays, $\mathrm{T}$ cells purified from thawed patient
PBMC samples were cultured at $10^{5}$ cells/well in 96-well plates for 3 days with the addition of medium alone, dexamethasone (Sigma-Aldrich) at concentrations between $3.125 \times 10^{6} \mathrm{M}$ and $5 \times 10^{5} \mathrm{M}$, or equivalent vehicle (ethanol) concentrations.

Antibodies and flow cytometry. Antibodies to phenotype Tcell subsets were directed against CD3 (BD Biosciences and Biolegend, San Diego, CA), CD4, CD8, CCR7, CD45RO, CD45RA, CD25, CD31, CLA, and CCR4 (BD Biosciences), CD127 (Beckman Coulter, Brea, CA), Integrin $\beta 7$, CCR9, CCR5, and CCR2 (Biolegend). Antibodies to detect intracellular targets were directed against IL-22 (eBioscience, San Diego, CA), IL-4, IL-10, IL-17, IFN $\gamma$, GM-CSF, and FOXP3 (BD Biosciences), BIM, BAK, and BCL-XL (Cell Signaling Technology, Danvers, MA), BAX and BCL-2 (Biolegend), and PUMA (Abcam, Cambridge, UK). For apoptosis assays, cells were stained with Annexin V and propidium iodide (PI; BD Biosciences) following the cell surface staining. Staining combinations and reagent details are provided in table e-1 at Neurology.org/nn. Counting beads (CountBright; Thermo Fischer Scientific, Waltham, MA) were added to obtain cell counts for T-cell survival assays, and samples were analyzed immediately using flow cytometry. For intracellular cytokine staining, phorbol 12myristate 13-acetate $(20 \mathrm{ng} / \mathrm{mL}$; Sigma-Aldrich, St. Louis, $\mathrm{MO}$ ), ionomycin (1 $\mu \mathrm{g} / \mathrm{mL}$; Sigma-Aldrich), and GolgiStop (Monensin; BD Biosciences) were added 4 hours prior to staining. Cells were processed and stained as previously described $^{21}$ and according to the manufacturer's recommendations (BD Biosciences and eBioscience). Cells were analyzed using an LSRFortessa Flow cytometer (BD Biosciences) and FlowJo software (Tree Star Inc., Ashland, OR). A representative example of $\mathrm{T}$-cell staining and the flow cytometry gating strategy is provided in figure e- 1 .

Statistical analyses. For analysis of longitudinal data from serially sampled patients with MS, we used a random coefficient mixed-effects analysis (SAS Software, Cary, NC), allowing efficient utilization of repeated measures data and modeling of treatment-related changes (fixed effects), while also accounting for between-patient variability (random effects). ${ }^{22}$ We used the Akaike Information Criterion (AIC) to compare the performance of 3 candidate models for the trajectories of immune cell subset losses following treatment initiation: a 12-month linear decay model (in which changes occurred uniformly over the 12-month follow-up); an exponential decay model (in which $75 \%$ of changes occurred in the first 6 months of treatment); and a 6 -month linear decay model (in which $100 \%$ of changes occurred in the first 6 months of treatment, with no changes thereafter).

For in vitro studies, a 2-way repeated measures analysis of variance (RM ANOVA) with Dunnett multiple comparisons test was used to compare the effects of different DMF and MMF doses across distinct T-cell subsets. Relative changes in cell viability were corrected for the differing basal viability in culture of each cell subset using the viability of the untreated condition (i.e., relative change in viability for subset $\mathrm{A}$ with DMF exposure $=\left(\%\right.$ viability subset $\mathrm{A}_{\mathrm{DMF}-\text { exposed }}$ - \%viability subset $A_{\text {Untreated }} / \%$ viability subset $A_{\text {Untreated }}$ ). One-way RM ANOVA with Sidak multiple comparisons tests were used to compare a single DMF dose between 3 or more T-cell subsets, and paired $t$ tests were used for the same analyses when only $2 \mathrm{~T}$-cell subsets were compared. One-way RM ANOVA or paired $t$ tests were used for all other pre- vs post-treatment comparisons. $p$ Values, adjusted for 
multiple comparisons, of $\leq 0.05$ were considered statistically significant. Analyses were performed using Prism 7 (GraphPad Software, La Jolla, CA).

Standard protocol approvals, registrations, and patient consents. The study was approved by the Institutional Review Board of McGill University. All participants provided written informed consent.

RESULTS In vivo kinetics of DMF-induced lymphopenia and early preferential loss of $\mathrm{CD8}^{+}$cells in patients with MS. We considered whether assessing the trajectories of T-cell subset losses, based on serial sampling of DMF-treated patients with MS and a random coefficient mixed-effects analysis, would provide clues into the mechanism/s underlying the previously reported ${ }^{14-16}$ differential effect of treatment on $\mathrm{CD}^{+}$vs $\mathrm{CD}^{+}$T-cell subsets. Comparing the performance of the 3 candidate models tested using the AIC, we found that the exponential decay model (in which $75 \%$ of changes occur in the first 6 months of treatment) was best fit in $72 \%$ of $\mathrm{T}$-cell trajectories tested. The second best performing model (best fit in only $22 \%$ of cases) was the 6-month linear decay model. The superiority of the exponential model and the 6-month linear decay model over the 12-month linear decay model in $94 \%$ of cases indicates that the majority (between $75 \%$ and $100 \%)$ of $\mathrm{T}$-cell losses are occurring in the first 6 months of treatment. For simplicity, we used the best performing exponential decay model for all subsequent analyses. By 12 months, TLCs decreased by an average of $48 \%$, from $2.02 \times 10^{9}$ cells/L pretreatment to $1.04 \times 10^{9}$ cells/L at 12 months $(p=0.0027$; figure $1 \mathrm{~A})$, with total $\mathrm{CD}^{+}$ T-cell counts decreasing by an average of $54 \%(p=$ 0.0062 ; figure $1 \mathrm{~B})$. Within the $\mathrm{CD}^{+} \mathrm{T}$-cell population, $\mathrm{CD}^{+}$counts decreased from an average of $0.47 \times 10^{9}$ cells $/ \mathrm{L}$ pretreatment to 0.11 $\times 10^{9}$ cells $/ \mathrm{L}$ at 12 months, representing a $77 \%$ decrease $(p=0.0498$; figure $1 \mathrm{C})$, whereas $\mathrm{CD}^{+}$ counts decreased by only $44 \%$, from 1.02 to 0.57 $\times 10^{9}$ cells $/ \mathrm{L}(p=0.0028$; figure $1 \mathrm{D})$, leading to an increase in the CD4:CD8 ratios from 3.2 pretreatment to 4.9 by month 12 ( $p=0.0026$; figure $1 \mathrm{E}$ ). Our results suggested that although the magnitude of DMF-induced T-cell loss was greater for the $\mathrm{CD}^{+} \mathrm{T}$ cells than $\mathrm{CD}^{+} \mathrm{T}$ cells

Figure 1 DMF treatment in vivo reduces lymphocyte and T-cell counts

A. TLC

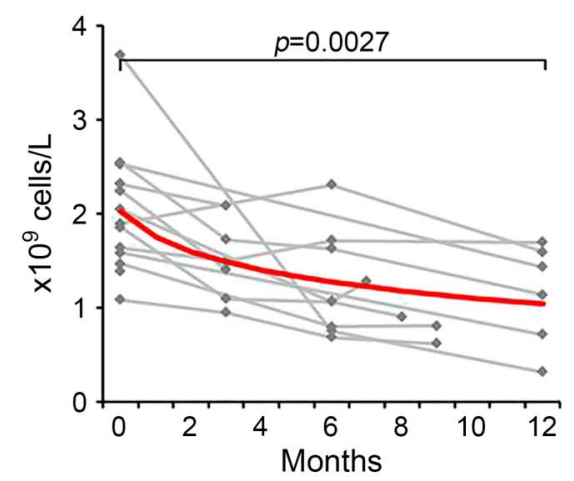

B. $\mathrm{CD} 3+$ count

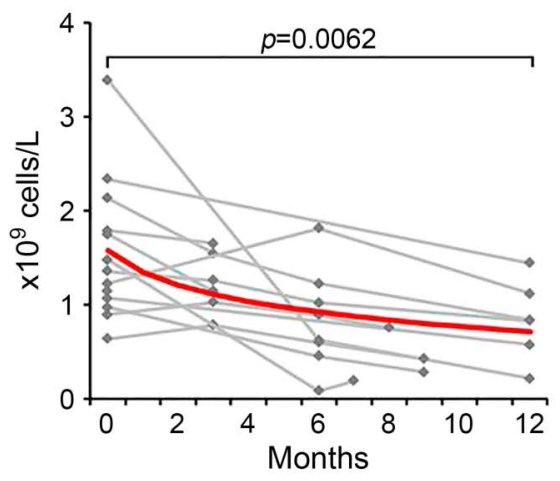

C. CD8+ count

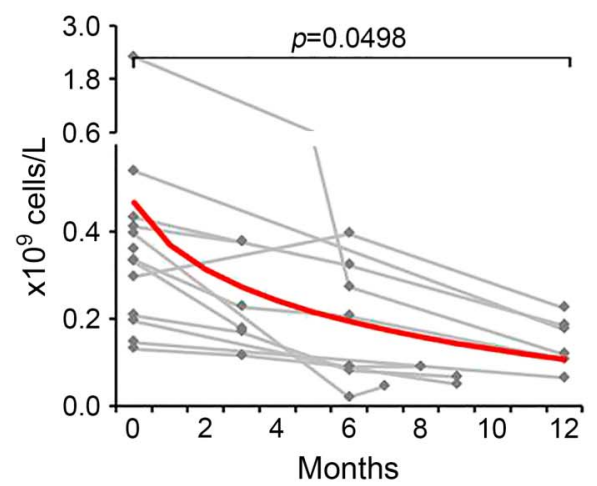

D. CD4+ count

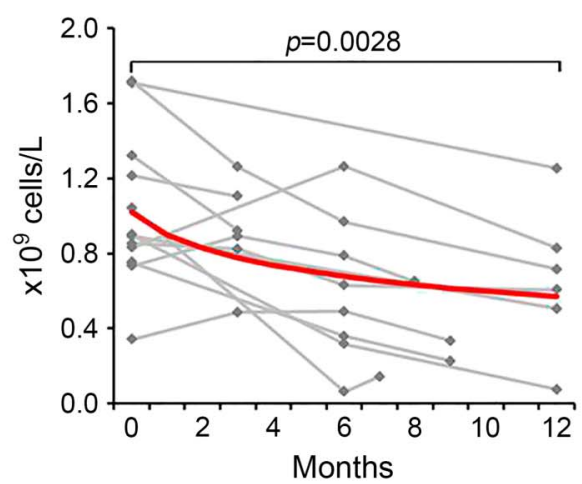

E. $\mathrm{CD} 4+: \mathrm{CD} 8+$ ratio

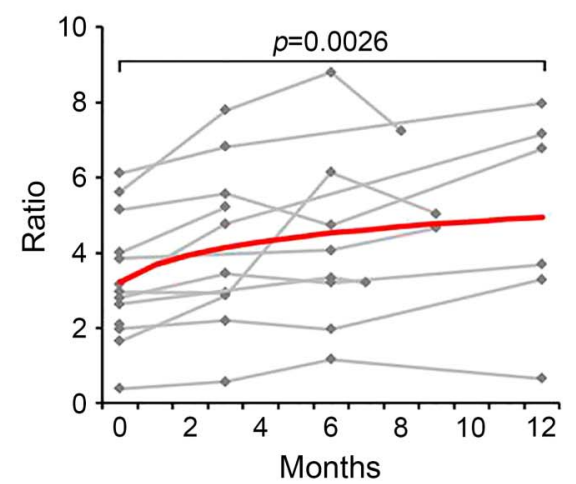

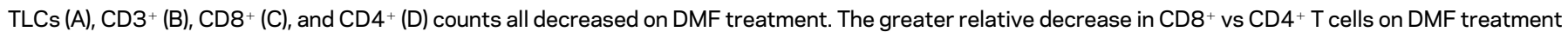

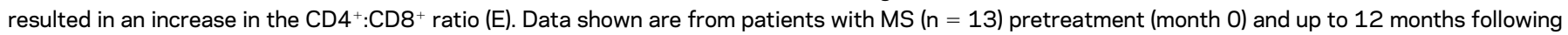

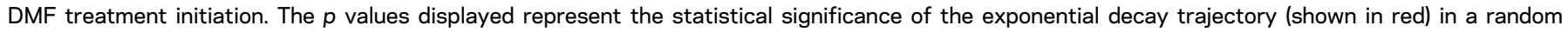
coefficient mixed-effects model. Individual patient trajectories are shown in gray. DMF = dimethyl fumarate; TLC = total lymphocyte count. 
(as previously reported ${ }^{14-16}$ ), the similar trajectories of decreased counts are compatible with a common mechanism underlying losses of both cell subsets.

DMF induces direct $\mathrm{T}$-cell apoptosis in vitro, with differential effects on $\mathrm{CD8}^{+}$compared with $\mathrm{CD4}^{+} \mathrm{T}$ cells. Examination of the in vitro effects of DMF and MMF on T-cell survival within PBMC revealed that exposure to DMF, but not MMF, caused dose-dependent decreases in survival of $\mathrm{CD}^{+} \mathrm{T}$ cells, including both $\mathrm{CD}^{+}$and $\mathrm{CD}^{+}{ }^{+} \mathrm{T}$ cells (figure 2A). This dose-dependent decreased survival reflected apoptotic cell death (figure $2 \mathrm{~B}$ ), such that the frequency of apoptotic (Annexin $\mathrm{V}+/ \mathrm{PI}+$ ) $\mathrm{CD}^{+}$cells was $9.8 \%$ with vehicle alone, vs $19.5 \%$ for DMF $10 \mu \mathrm{M}$; $43.3 \%$ for DMF $25 \mu \mathrm{M}$; and $60.4 \%$ for DMF $50 \mu \mathrm{M}$ (all $p=0.0001$ ). Mirroring the preferential losses of $\mathrm{CD}^{+}$vs $\mathrm{CD}^{+}$ $\mathrm{T}$ cells that we observed in treated patients, the in vitro apoptotic cell death was approximately twice as marked for $\mathrm{CD}^{+} \mathrm{T}$ cells compared with $\mathrm{CD}^{+} \mathrm{T}$ cells. For example, at the DMF $25 \mu \mathrm{M}$ exposure, the decrease in cell viability (relative to the untreated condition) was $52 \%$ for $\mathrm{CD}^{+} \mathrm{T}$ cells vs $25 \%$ for $\mathrm{CD}^{+} \mathrm{T}$ cells $(p=0.0001$; figure $2 \mathrm{C}$ ). A representative example of Annexin V/PI staining of

Figure 2 DMF causes T-cell apoptosis in vitro with a preferential effect on CD8 ${ }^{+} \mathrm{T}_{\text {cells }}$

A. T-cell survival

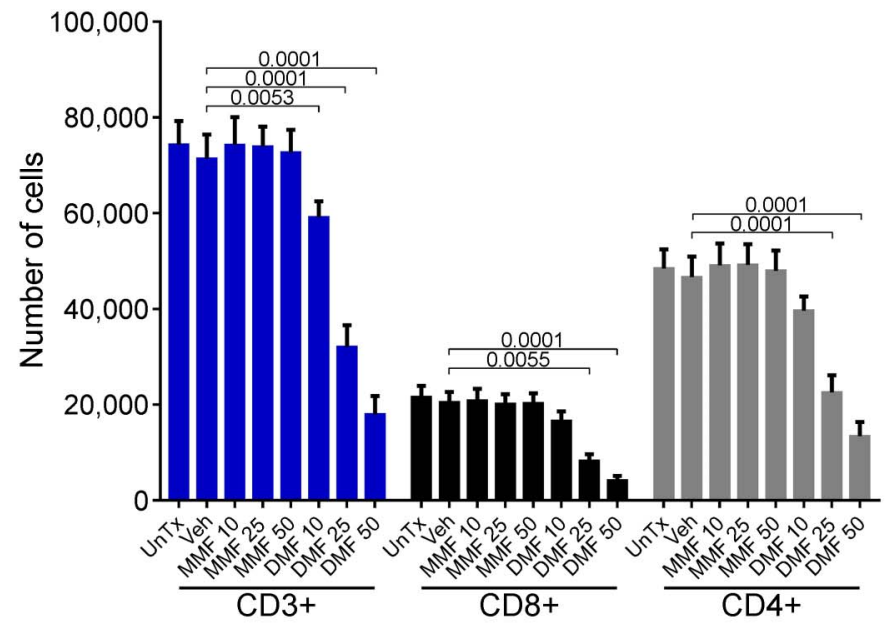

C. CD8+ vs CD4+

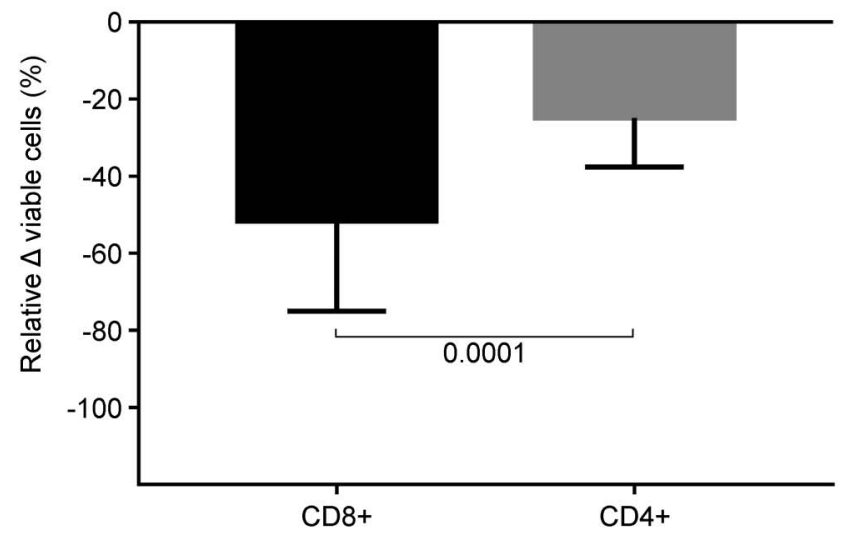

B. T-cell apoptosis (PBMC cultures)

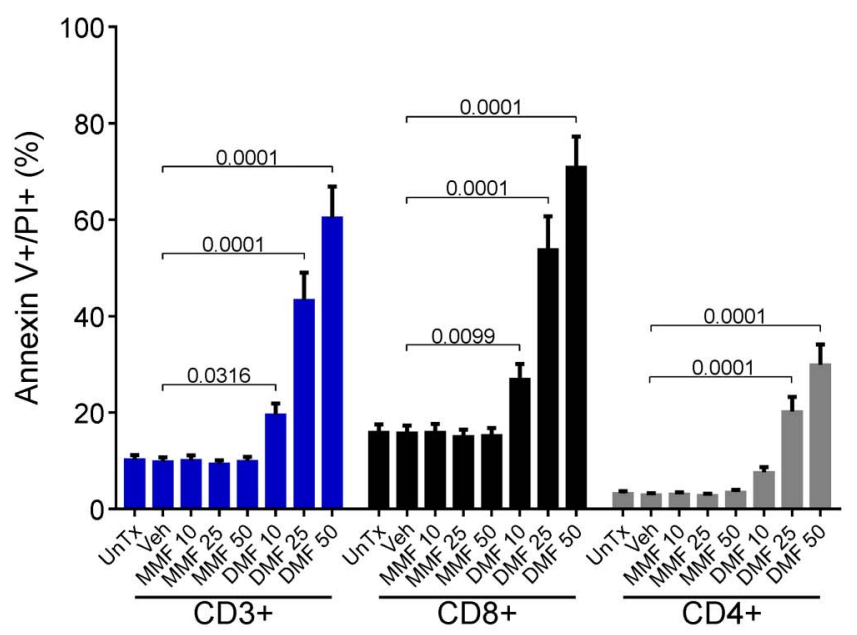

D. T-cell apoptosis (purified T cells)

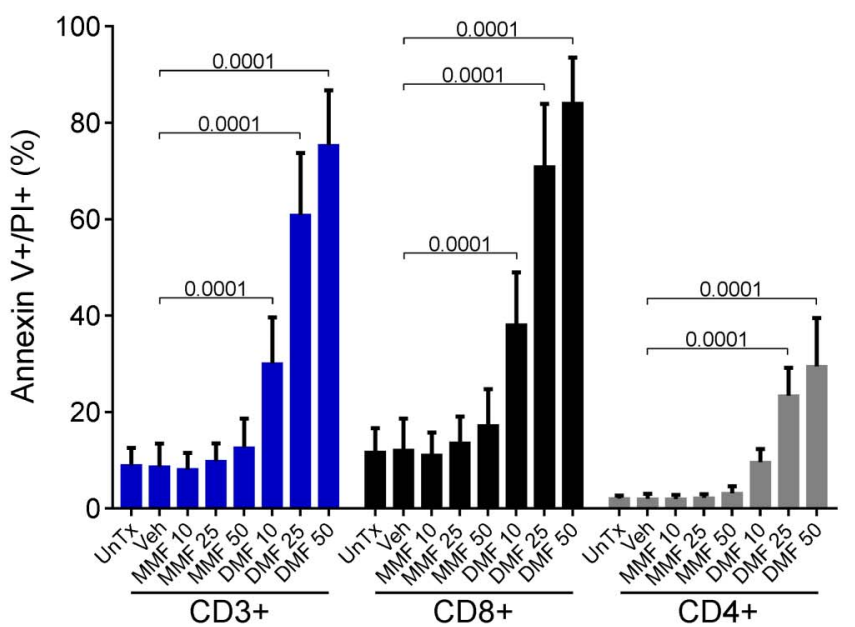

Healthy control $(n=10)$ PBMC were cultured with the addition of DMF, MMF, vehicle alone, or medium alone. Total $C D 3^{+}, \mathrm{CD}^{+}$, and $\mathrm{CD} 8^{+} \mathrm{T}^{-c e l l}$ subsets showed a dose-dependent decrease in survival after the addition of DMF, whereas MMF and vehicle alone had no effect (A). The proportion of apoptotic cells within $\mathrm{CD}^{+}, \mathrm{CD}^{+}$, and $\mathrm{CD}^{+}$subsets increased with increasing DMF exposure (B). Relative to viability in untreated cultures, there was significantly greater DMF-induced loss of viability among $\mathrm{CD}^{+}{ }^{*}$ vs $\mathrm{CD} 4^{+}$T cells following a $25 \mu \mathrm{M}$ DMF exposure (C). The pattern of DMF-induced apoptosis of CD3 ${ }^{+}, \mathrm{CD}^{+}{ }^{+}$, and $\mathrm{CD}^{+} \mathrm{T}$ cells was also seen in purified T-cell cultures $(n=4)(D)$. Statistical analyses used were a 2-way repeated measures ANOVA with adjustment for multiple comparisons using Dunnett test $(\mathrm{A}, \mathrm{B}$, and $\mathrm{D})$ and a paired $t$ test $(\mathrm{C})$. ANOVA = analysis of variance; DMF = dimethyl fumarate; $\mathrm{MMF}=$ monomethyl fumarate; PBMC = peripheral blood mononuclear cells; UnTx = untreated; Veh = vehicle alone. 
$\mathrm{CD}^{+}$and $\mathrm{CD}^{+}$T-cell subsets under each condition is provided in figure e-2. Because DMF is known to affect survival and function of myeloid cells, we sought to distinguish a direct pro-apoptotic effect of DMF on $\mathrm{T}$ cells from an indirect effect through supporting myeloid cells within the PBMC. We repeated the above experiments on purified $\mathrm{CD}^{+} \mathrm{T}$ cells and observed the same dosedependent pattern of DMF-induced apoptosis among total $\mathrm{CD}^{+} \mathrm{T}$ cells and the preferential loss of $\mathrm{CD} 8^{+}$ compared with $\mathrm{CD}^{+} \mathrm{T}$ cells (figure 2D).

Memory $\mathbf{T}$ cells exhibit greater susceptibility to DMFinduced apoptosis in vitro. To assess the relative susceptibility of distinct subsets of $\mathrm{CD}^{+}{ }^{+}$and $\mathrm{CD}^{+} \mathrm{T}$ cells to DMF-induced apoptosis, staining with CD45RA and CCR7 was used to distinguish $\mathrm{CD}^{+}$- and $\mathrm{CD}^{+}$-naive $\mathrm{T}$ cells (TN; CD45RA+CCR7+), central memory (TCM; CD45RA-CCR7+), and effector memory (TEM; CD45RA-CCR7-) T cells, as well as terminally differentiated effector memory (TEMRA; CD45RA+CCR7-) $\mathrm{CD}^{+}$ cells within PBMC. Although all subsets within both $\mathrm{CD}^{+}$and $\mathrm{CD}^{+}{ }^{+} \mathrm{T}$ cells exhibited a degree of dose-dependent DMF-induced apoptosis (and no effect of MMF) (figure 3, A and B), decreased viability was more pronounced for the memory compared with the naive T-cell subsets. Among $\mathrm{CD}^{+} \mathrm{T}$ cells exposed to $25 \mu \mathrm{M}$ DMF, decreased viability was least pronounced for $\mathrm{TN}(-10 \%)$, compared with all memory subsets including TCM $(-63 \%, p<0.0001)$, TEM (-70\%, $p<0.0001)$, and TEMRA $(-54 \%, p=0.0003)$ (figure 3C). Similarly, the decrease in $\mathrm{CD}^{+}$T-cell viability following $25 \mu \mathrm{M}$ DMF exposure was least among TN $(-15 \%)$ compared with both TCM $(-30 \%$, $p=0.0269)$ and TEM $(-41 \%, p=0.0013)$ subsets (figure 3D). The same differential effects on memory and naive $T$-cell subsets were seen in experiments using purified $\mathrm{T}$ cells alone (data not shown). Across the same concentration range of $\mathrm{DMF}$, regulatory $\mathrm{T}$ cells (defined as $\mathrm{CD} 4^{+} \mathrm{CD} 25$

Figure 3 Memory T-cell subsets and conventional T-cell subsets are most susceptible to in vitro DMF-induced apoptosis

A. CD8 subset apoptosis

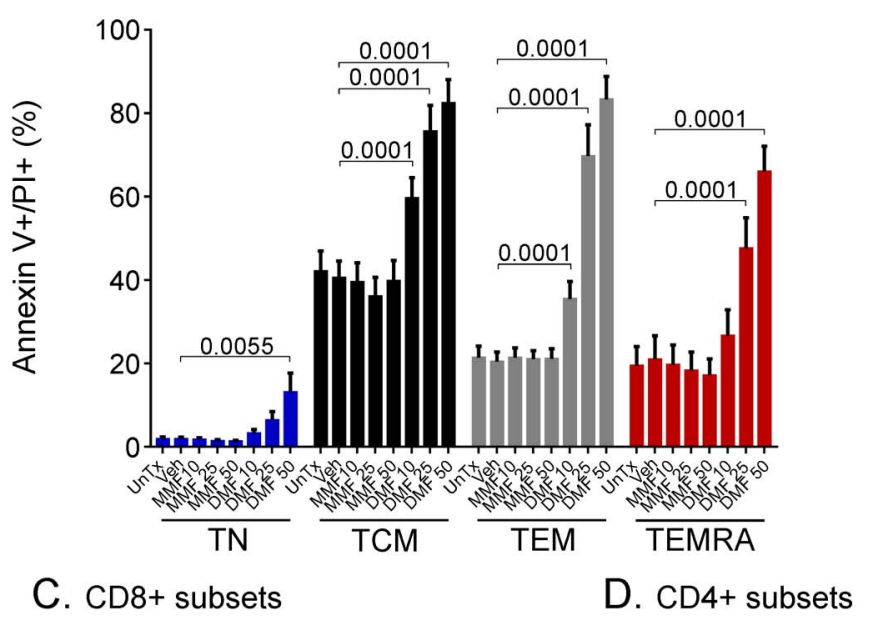

B. CD4 subset apoptosis

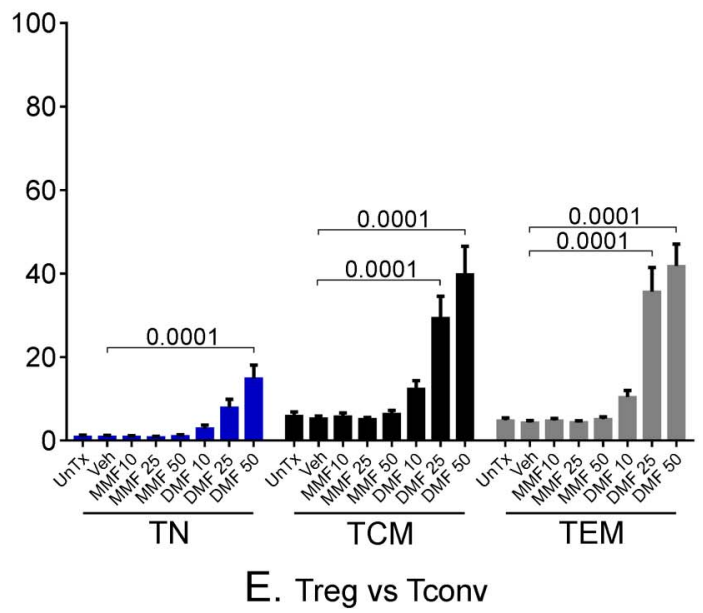

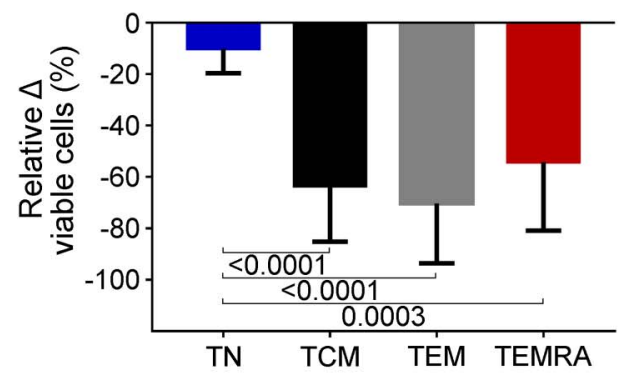
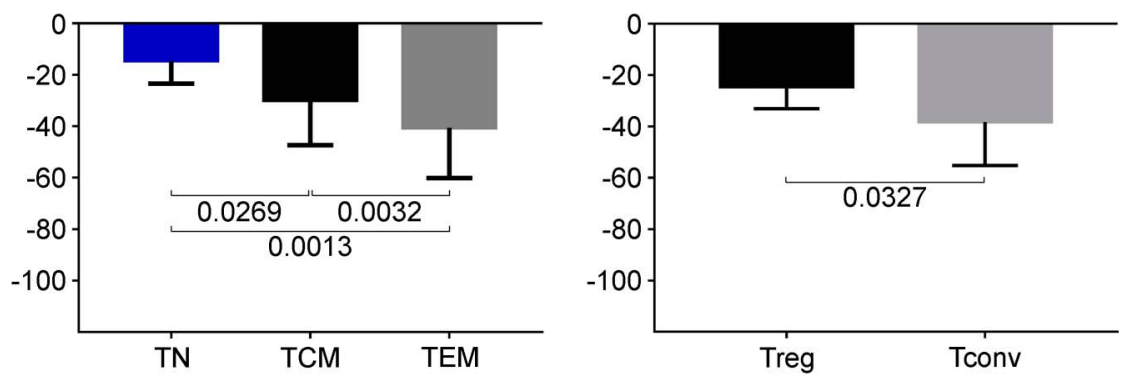

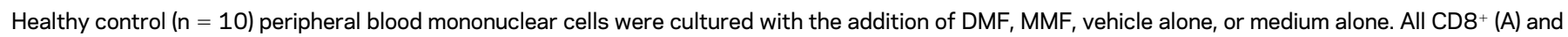

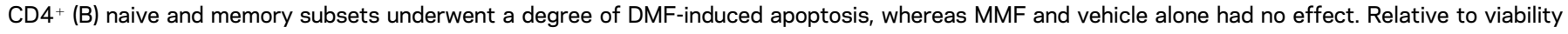

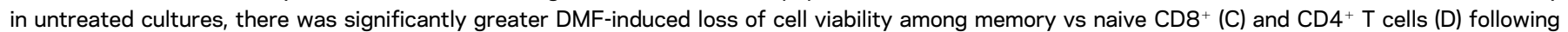

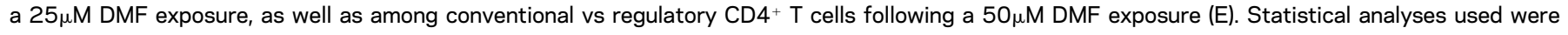

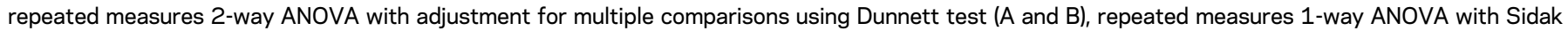

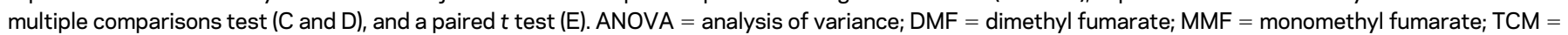

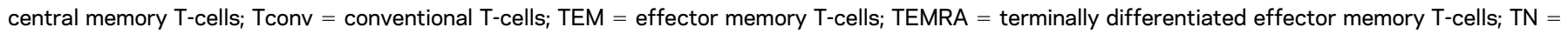
naïve T-cells; Treg = regulatory T-cells; UnTx = untreated; Veh = vehicle alone. 
${ }^{\text {hiCD127 }}{ }^{\text {low }}$ Tregs) exhibited lesser susceptibility to DMF-mediated apoptosis compared with conventional $\left(\mathrm{CD} 4^{+} \mathrm{CD} 25^{-}\right) \mathrm{T}$ cells, most notably at the higher DMF concentration (figure 3E).

The in vivo pattern of distinct T-cell subset losses in DMF-treated patients with MS recapitulates their preferential in vitro susceptibility to DMF-mediated apoptosis. We next observed that the in vitro patterns of DMF-mediated apoptosis in distinct T-cell subsets were recapitulated during in vivo DMF treatment of patients with MS, which induced greater losses of memory $\mathrm{T}$-cell subsets compared with naive $\mathrm{T}$ cells, leading to preferential decreases in frequencies of circulating TCM and TEM subsets (and relative increases in the frequencies of TN cells) within both the $\mathrm{CD}^{+}$and $\mathrm{CD}^{+}{ }^{+}$T-cell pools (figure 4, A-F). Examination of the kinetics of $\mathrm{CD}^{+}$recent thymic emigrants (RTEs; CD31+CD45RO-) emerging into the circulation of DMF-treated patients revealed that although RTE frequencies increased during treatment (figure $5 \mathrm{~A}$ ), their absolute counts remained relatively stable (figure $5 \mathrm{~B}$ ). In vivo treatment also resulted in decreased frequencies of the effector (Teff) $\mathrm{CD} 4+\mathrm{IFN} \gamma+$ (Th1) $\mathrm{T}$ cells (figure 5C) and $\mathrm{CD} 8+\mathrm{IFN} \gamma+(\mathrm{Tc1}) \mathrm{T}$ cells (figure 5D), in the face of lesser decreases in frequencies of $\mathrm{T}$ cells with regulatory phenotype $\left(\mathrm{CD} 4{ }^{+} \mathrm{CD} 25{ }^{\text {hi }} \mathrm{CD} 127^{\text {low }}\right.$ Tregs; figure $5 \mathrm{E}$ ), recapitulating the relative resistance of Tregs to the DMF-mediated apoptosis observed in vitro. Although DMF treatment of patients thus generally resulted in decreased absolute counts of T-cell subsets, the differential losses of these subsets in DMF-treated patients resulted in increased ratios of putatively antiinflammatory subsets to putatively proinflammatory subsets (figure e-3). For all T-cell subsets examined, the majority of in vivo changes occurred within the first 6 months of DMF treatment, again consistent with best-fit exponential decay trajectories.

DISCUSSION Using a combination of in vivo and in vitro approaches, our present study explored potential mechanisms underlying the preferential

Figure 4 DMF treatment leads to decreased memory T-cell subset frequencies and increased naive T-cell subset frequencies

A. CD8+TCM

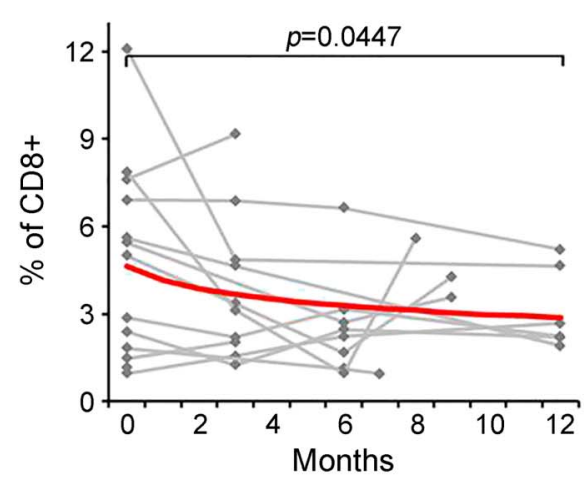

D. CD4+TCM

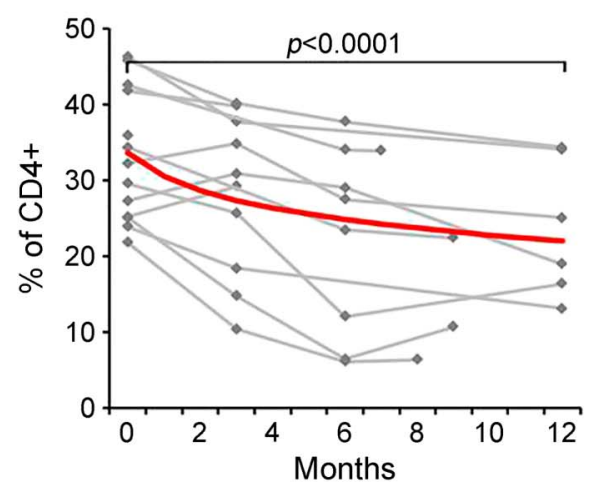

B. CD8+ TEM

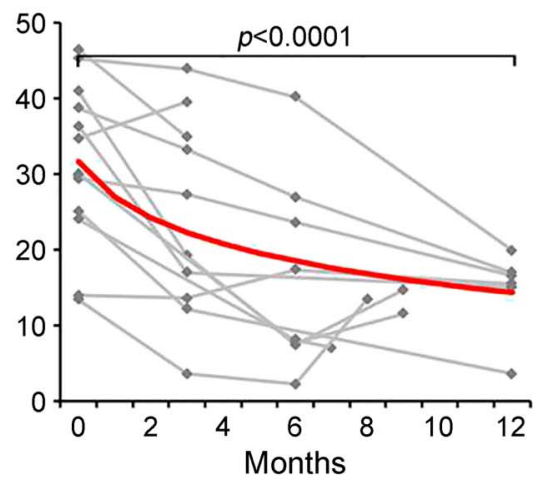

E. CD4+ TEM

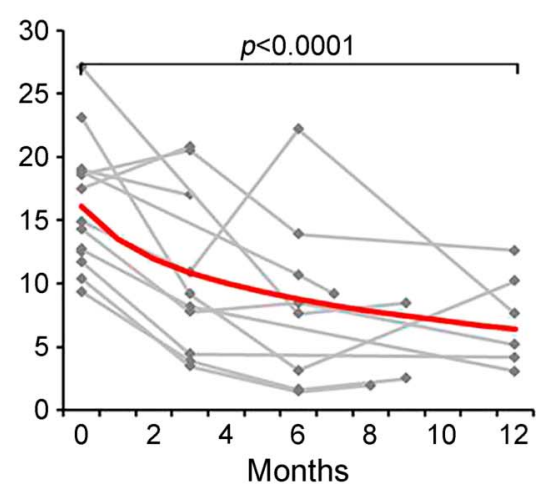

C. $C D 8+T N$

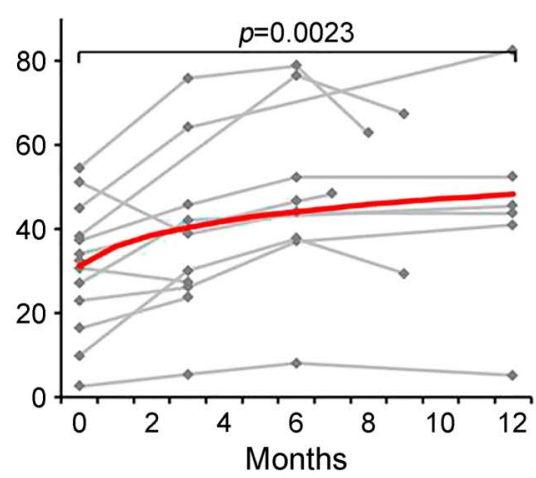

F. CD4+TN

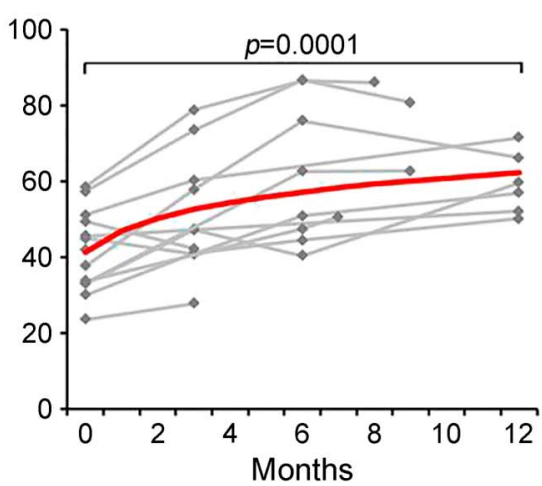

Among CD8 ${ }^{+}$T-cell subsets, central memory (A) and effector memory (B) populations decreased in frequency, whereas naive cells increased in frequency (C) with DMF treatment. This pattern was mirrored within the CD4 ${ }^{+}$T-cell pool: central memory (D) and effector memory (E) frequencies decreased, whereas a reciprocal increase in naive T-cell frequencies (F) was seen. Data shown are from patients with $M S(n=13)$ pretreatment (month 0$)$ and up to 12 months following DMF treatment initiation. The $p$ values displayed represent the statistical significance of the exponential decay trajectory (shown in red) in a random coefficient mixed-effects model. Individual patient trajectories are shown in gray. DMF = dimethyl fumarate; TCM = central memory T cell; TEM = effector memory $\mathrm{T}$ cell; $\mathrm{TN}=$ naive $\mathrm{T}$ cell. 


\section{A. CD4+ RTE frequency}

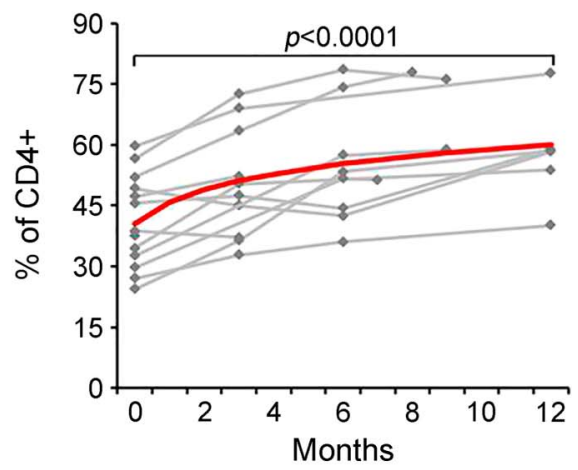

B. CD4+ RTE+ count

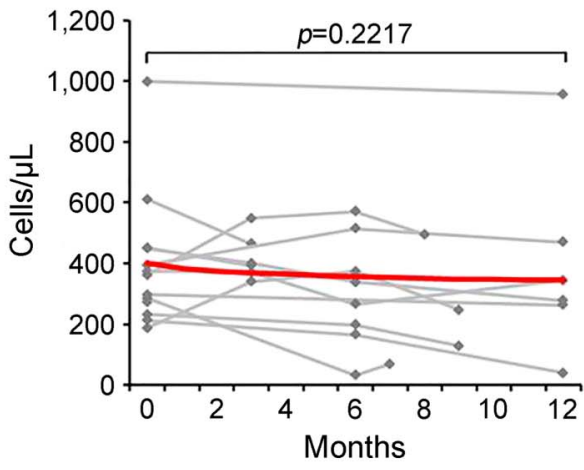

C. $\mathrm{CD} 4+\mathrm{IFNY}+$

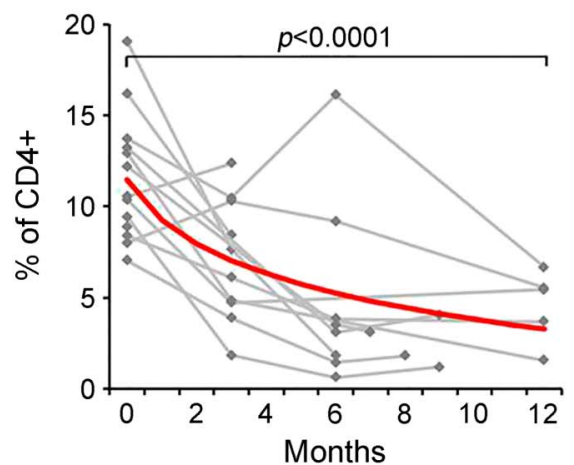

D. $\mathrm{CD} 8+\mathrm{IFNY}+$

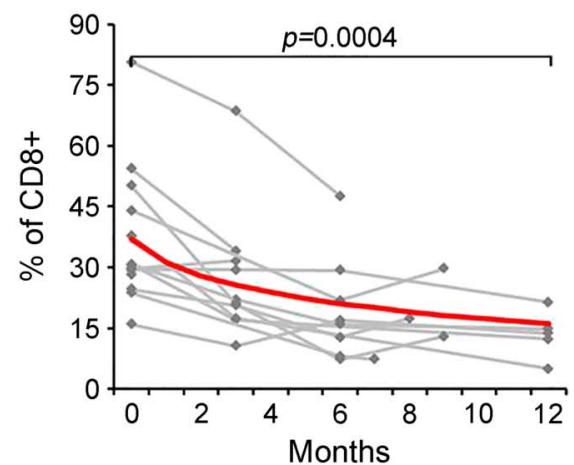

E. Treg

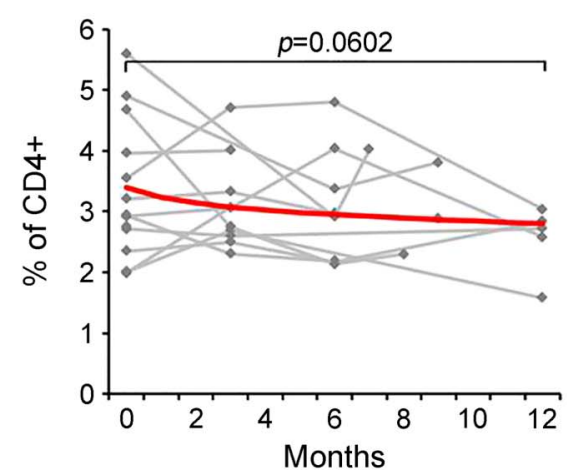

DMF treatment resulted in an increased frequency of circulating RTEs (A), although absolute counts of RTEs did not change (B). Proinflammatory IFN $\gamma$ expressing Th1 (C) and Tc1 (D) populations decreased in frequency with DMF treatment, whereas regulatory T-cell frequency remained relatively stable (E). Data shown are from patients with MS $(n=13)$ pretreatment (month 0$)$ and up to 12 months following DMF treatment initiation. The $p$ values displayed represent the statistical significance of the exponential decay trajectory (shown in red) in a random coefficient mixed-effects model. Individual patient trajectories are shown in gray. DMF = dimethyl fumarate; RTE = recent thymic emigrant; Treg = regulatory $\mathrm{T}$ cell.

losses of $\mathrm{CD} 8^{+}$vs $\mathrm{CD} 4^{+} \mathrm{T}$ cells observed in DMFtreated patients. We applied a random coefficient mixed-effects model that incorporated serial data collected over the 12-month study period, enabling us to assess the kinetics of cell subset losses in individual patients. The best-fit model for both $\mathrm{CD}^{+}$and $\mathrm{CD}^{+}{ }^{+}$T-cell subsets involved the majority of losses $(>75 \%)$ occurring during the first 6 months of treatment, with lesser ongoing losses continuing to occur thereafter. These common trajectories suggested that although DMF treatment results in greater losses of $\mathrm{CD}^{+}$ compared with $\mathrm{CD}^{+} \mathrm{T}$ cells, a shared mechanism may underlie both subset losses.

We considered whether apoptotic cell death may represent such a common mechanism because FAEs have been shown to induce apoptosis in a number of cell types. ${ }^{4,9,23,24}$ Assessment of the in vitro effects of both MMF and DMF on human T-cell subset survival and apoptotic cell death within PBMC demonstrated that exposure to DMF (but not MMF) induced dose-dependent apoptotic T-cell losses. Although early work with FAEs suggested that the only active metabolite was MMF (with DMF rapidly converting to MMF in vivo), ${ }^{25}$ our findings are consistent with multiple studies that have since attributed important biological activities also to DMF. ${ }^{4,9,24,26}$ A degree of systemic penetrance of DMF has been reported, with DMF-glutathione conjugates being measureable in the plasma and brain of rats following oral administration of DMF, ${ }^{27}$ and similar DMF-derived conjugates found in the urine of DMF-treated psoriasis patients. ${ }^{28}$ Since Michell-Robinson et al. ${ }^{9}$ recently reported that DMF can be cytotoxic to human monocytes, we assessed the effects of DMF on purified $\mathrm{T}$ cells and documented that the dosedependent induction of T-cell apoptosis could occur as a direct effect, rather than reflecting an indirect effect mediated by myeloid cells within the PBMC.

A main discovery was that the propensity to DMF-induced apoptosis varied substantially across human $\mathrm{T}$-cell subsets, with $\mathrm{CD} 8^{+} \mathrm{T}$ cells exhibiting greater susceptibility than $\mathrm{CD}^{+} \mathrm{T}$ cells, and with memory $\mathrm{CD}^{+}$and $\mathrm{CD}^{+}{ }^{+} \mathrm{T}$-cell subsets also being 
disproportionately affected as compared to naive subsets. These differential in vitro susceptibilities to apoptosis directly mirrored our findings in patients treated in vivo with DMF, which are consistent with the previously reported preferential reductions in $\mathrm{CD}^{+14-16}$ and memory ${ }^{15,16} \mathrm{~T}$-cell subsets. In this regard, several prior studies have suggested that different $\mathrm{T}$-cell subsets may be more or less prone to death, including apoptotic cell death. ${ }^{29-31}$ For example, TN and TCM subsets of both $\mathrm{CD}^{+}$and $\mathrm{CD}^{+}{ }^{+} \mathrm{T}$ cells have been shown to be more susceptible than TEM and TEMRA subsets to major apoptotic pathways (death receptor, mitochondrial and endoplasmic reticulum pathways). ${ }^{29}$

We considered whether in vivo treatment with DMF might render circulating $T$ cells more susceptible to apoptosis, although found no significant differences between the degree of dexamethasone-induced $\mathrm{T}$-cell apoptosis comparing pre- and post-DMF treatment samples across a range of dexamethasone concentrations (figure e-4). This suggests that the $\mathrm{T}$ cells that continue to circulate in DMF-treated patients are not more susceptible to apoptosis, rather they represent surviving cells that may have been relatively less sensitive to DMF-induced cell death (i.e., relatively treatment resistant). Differences in the balance and timing of expression of pro-apoptotic and antiapoptotic molecules have also been implicated in differential susceptibilities to apoptosis. ${ }^{29,31}$ When examining circulating T-cell expression levels of such apoptosis-related molecules' pre- and post-DMF treatment, we found no significant changes in the pro-apoptotic molecules BIM, PUMA, BAX or $\mathrm{BAK}$, although noted a marginal increase in their expression of the antiapoptotic molecule BCL-2 (table e-2). This would be consistent with the possibility that the $T$ cells that remain in the circulation in DMF-treated patients are less susceptible to in vivo DMF-induced apoptotic cell death.

One notes that an alternative explanation for differential T-cell apoptosis could include different degrees of $\mathrm{T}$-cell exposure to $\mathrm{DMF}$ in different anatomic compartments in vivo. For example, one might expect greater exposure to DMF for T-cells homing to the gut, the site of DMF hydrolysis to MMF. We examined relative reductions in circulating $\mathrm{T}$ cells expressing homing markers for the gut $(\mathrm{CCR} 9+$ beta7integrin +$)$, skin (CLA+CCR4+), and brain (CCR2+CCR5+) following DMF treatment initiation and found no evidence of a preferential effect of DMF on gut-homing $T$ cells (figure e-5). Inhibition of proliferation could represent another alternate explanation for the differential lymphopenia observed with DMF treatment. Memory and naive $\mathrm{T}$ cells are known to proliferate at different rates, with a greater steady-state proliferation rate of memory $\mathrm{T}$ cells, ${ }^{32}$ and antiproliferative effects of FAEs (including both DMF and MMF) have been reported. ${ }^{5,33}$

To assess the compensatory response to DMFinduced lymphopenia, we examined the kinetics of emergence of $\mathrm{CD}^{+}$RTEs into the circulation of treated patients. Although RTE frequencies appeared to increase during treatment, their absolute counts in fact remained relatively stable. This suggests that, on one hand, DMF treatment does not entirely abrogate the generation and release of RTEs, but that the numbers of released RTEs are nonetheless insufficient to replete the DMF-induced losses of T cells during 12 months of treatment.

The relevance of understanding mechanisms underlying DMF-induced lymphopenia is underscored by recent reports of PML developing as a rare complication of DMF treatment in patients with MS. ${ }^{17,18}$ Such occurrences of DMF-associated PML in both patients with MS and psoriasis have been associated with severe lymphopenia, typically defined as TLC $<500$ cells $/ \mathrm{mm}^{3}$, which occurs in only $\sim 5 \%$ of treated patients. Although particular mechanisms underlying DMF-induced lymphopenia may be common in all treated patients, additional features likely underlie the particularly severe lymphopenia experienced by a small proportion of patients, which would not be captured in this study and merit further investigation. Lesser grades of lymphopenia remain important, however, as highlighted by the recent report ${ }^{19}$ of PML in a DMF-treated psoriasis patient with a documented TLC nadir of only 792 cells $/ \mathrm{mm}$. This raises the possibility that subset-specific losses, such as the disproportionate losses of $\mathrm{CD}^{+} \mathrm{T}$ cells or possibly of memory $\mathrm{T}$-cell subsets as observed in our study and recently by Longbrake et al., ${ }^{15}$ may be more importanat to monitor than global lymphopenia.

Given the important and opposing roles ascribed to effector $\mathrm{T}$ cells and regulatory $\mathrm{T}$ cells in the pathogenesis of MS, we investigated whether DMF may differentially affect these subsets, both in vivo and in vitro. We found regulatory $\mathrm{T}$ cells to be more resistant to apoptosis following DMF exposure in vitro compared with conventional T cells and found correspondingly greater losses of proinflammatory cytokine-expressing effector $\mathrm{T}$ cells vs regulatory $\mathrm{T}$ cells in vivo, in keeping with a recent study reporting that the ratio of Tregs to chemokine-defined Th1 and Th17 populations was increased in DMF-treated patients. ${ }^{16}$ Our results raise the possibility that differential susceptibility to apoptosis, and the resultant change in the balance between regulatory and effector cells in patients, may contribute to the therapeutic mode of action of DMF in MS. 
We propose that differential susceptibility of distinct T-cell subsets to DMF-induced apoptosis may contribute to both the efficacy and safety profiles of DMF in patients with MS. Although such a mechanism need not exclude previously implicated modes of action of DMF, ${ }^{3-11}$ it will be interesting to observe whether future studies monitoring distinct T-cell subsets (rather than just TLCs) will provide more meaningful insights into both the safety and efficacy of DMF treatment.

\section{AUTHOR CONTRIBUTIONS}

M.G., A.R., and R.L. contributed to the design of the study, analysis and interpretation of the data, and drafting and revising of the manuscript for intellectual content. A.E. contributed to analysis and interpretation of the data and drafting and revising of the manuscript for intellectual content. F.L. and F.Z. contributed to the design of the study and revising of the manuscript for intellectual content. P.S.G., J.A., and A.B.-O. contributed to the design of the study, analysis and interpretation of the data, and drafting and revising of the manuscript for intellectual content.

\section{ACKNOWLEDGMENT}

The authors acknowledge Camille Stegen for her management of the McGill University Department of Microbiology and Immunology flow cytometry facility. They thank all the patients who donated blood for this study.

\section{STUDY FUNDING}

No targeted funding.

\section{DISCLOSURE}

M. Ghadiri received travel funding from Genzyme, BioCSL, Biogen Idec, and Novartis; received fellowship funding and a scholarship from Novartis; and received research support from the University of Sydney. A. Rezk and R. Li report no disclosures. A. Evans is employed by Taylor Fry Consulting Actuaries. F. Luessi served on the scientific advisory board for Roche Pharma and received travel grants from Teva Pharma and Merck Serono. F. Zipp received travel funding from Teva, Novartis, Merck Serono, Bayer, Biogen Idec, Ono, Genzyme, Sanofi-Aventis, and Octapharma; has consulted for Teva, Merck Serono, Novartis, Bayer HealthCare, Biogen Idec Germany, Ono, Genzyme, Sanofi-Aventis, and Octapharma; and received research support from DFG, BMBF KKNMS, PCORI PRAG-MS, Progressive MS Alliance, Teva, Novartis, Merck Serono, and Bayer. P.S. Giacomini served on the scientific advisory board for Allergan, Bayer HealthCare, Biogen Idec, EMD Serono, Genzyme, Merz, Novartis, Roche, and Teva Neuroscience; received travel funding from Bayer, Biogen Idec, EMD Serono, Genzyme, Novartis, and Teva Neuroscience; has consulted for Allergan, Bayer HealthCare, Biogen Idec, EMD Serono, Genzmye, Merz, Novartis, Roche, and Teva Neuroscience; and received research support form Biogen Idec and Teva Neuroscience. J.P. Antel served on the scientific advisory board for Sanofi-Aventis, Biogen Idec, Genzyme, Novartis, and Celgene; received travel funding and/or speaker honoraria from Novartis, Biogen Idec, and Celegene; served as editor for the Americas Multiple Sclerosis Journal; served on the editorial board for the Journal of Neuroimmunology and the Journal of Neuroscience Research; received publishing royalties from Oxford University Press; consulted for Novartis, Biogen Idec, Sanofi-Aventis, and Celgene; and received research support from Novartis, Revalesio, Mallinckrodt, Multiple Sclerosis Society of Canada Medical Research Council-Great Britain. A. Bar-Or served on the scientific advisory board for DioGenix, Receptos-Celgene, Roche/Genentech, Novartis, GSK, Guthy Jackson Greater Good Foundation, and Immune Tolerance Network; received travel funding and/or speaker honoraria from Receptos-Celgene, Roche/Genentech, Novartis, Sanofi-Genzyme, and GSK; served on the editorial board for Neurology and Clinical and Experimental Neuroimmunology; consulted for DioGenix, Receptos-Celgene, Roche/Genentech, Novartis, Sanofi-Genzyme, and GSK; and received research support from Novartis and Genzyme-Sanofi. Go to Neurology.org/nn for full disclosure forms.

Received December 16, 2016. Accepted in final form January 30, 2017.

\section{REFERENCES}

1. Gold R, Kappos L, Arnold DL, et al. Placebo-controlled phase 3 study of oral BG-12 for relapsing multiple sclerosis. N Engl J Med 2012;367:1098-1107.

2. Fox RJ, Miller DH, Phillips JT, et al. Placebo-controlled phase 3 study of oral BG-12 or glatiramer in multiple sclerosis. N Engl J Med 2012;367:1087-1097.

3. de Jong R, Bezemer AC, Zomerdijk TPL, van de PouwKraan T, Ottenhoff THM, Nibbering PH. Selective stimulation of $\mathrm{T}$ helper 2 cytokine responses by the anti-psoriasis agent monomethylfumarate. Eur J Immunol 1996;26:2067-2074.

4. Zhu K, Mrowietz U. Inhibition of dendritic cell differentiation by fumaric acid esters. J Invest Dermatol 2001;116: 203-208.

5. Lehmann JC, Listopad JJ, Rentzsch CU, et al. Dimethylfumarate induces immunosuppression via glutathione depletion and subsequent induction of heme oxygenase 1. J Invest Dermatol 2007;127:835-845.

6. Ghoreschi K, Bruck J, Kellerer C, et al. Fumarates improve psoriasis and multiple sclerosis by inducing type II dendritic cells. J Exp Med 2011;208:2291-2303.

7. Linker RA, Lee DH, Ryan S, et al. Fumaric acid esters exert neuroprotective effects in neuroinflammation via activation of the Nrf2 antioxidant pathway. Brain 2011; 134:678-692.

8. Schulze-Topphoff U, Varrin-Doyer M, Pekarek K, et al. Dimethyl fumarate treatment induces adaptive and innate immune modulation independent of Nrf2. Proc Natl Acad Sci USA 2016;113:4777-4782.

9. Michell-Robinson MA, Moore CS, Healy LM, et al. Effects of fumarates on circulating and CNS myeloid cells in multiple sclerosis. Ann Clin Transl Neurol 2016;3:27-41.

10. Luchtman D, Gollan R, Ellwardt E, et al. In vivo and in vitro effects of multiple sclerosis immunomodulatory therapeutics on glutamatergic excitotoxicity. J Neurochem 2016;136: 971-980

11. Chen H, Assmann JC, Krenz A, et al. Hydroxycarboxylic acid receptor 2 mediates dimethyl fumarate's protective effect in EAE. J Clin Invest 2014;124:2188-2192.

12. Moharregh-Khiabani D, Linker RA, Gold R, Stangel M. Fumaric acid and its esters: an emerging treatment for multiple sclerosis. Curr Neuropharmacol 2009;7:60-64.

13. Dubey D, Kieseier BC, Hartung HP, et al. Dimethyl fumarate in relapsing-remitting multiple sclerosis: rationale, mechanisms of action, pharmacokinetics, efficacy and safety. Expert Rev Neurother 2015;15:339-346.

14. Spencer CM, Crabtree-Hartman EC, Lehmann-Horn K, Cree BAC, Zamvil SS. Reduction of CD8+ T lymphocytes in multiple sclerosis patients treated with dimethyl fumarate. Neurol Neuroimmunol Neuroinflamm 2015;2: e76. doi: 10.1212/NXI.0000000000000076.

15. Longbrake EE, Ramsbottom MJ, Cantoni C, Ghezzi L, Cross AH, Piccio L. Dimethyl fumarate selectively reduces memory $\mathrm{T}$ cells in multiple sclerosis patients. Mult Scler 2016;22:1061-1070.

16. Gross CC, Schulte-Mecklenbeck A, Klinsing S, PosevitzFejfár A, Wiendl $\mathrm{H}$, Klotz L. Dimethyl fumarate 
treatment alters circulating $\mathrm{T}$ helper cell subsets in multiple sclerosis. Neurol Neuroimmunol Neuroinflamm 2016; 3:e183. doi: 10.1212/NXI.0000000000000183.

17. Rosenkranz T, Novas M, Terborg C. PML in a patient with lymphocytopenia treated with dimethyl fumarate. $\mathrm{N}$ Engl J Med 2015;372:1476-1478.

18. Lehmann-Horn K, Penkert H, Grein P, et al. PML during dimethyl fumarate treatment of multiple sclerosis: how does lymphopenia matter? Neurology 2016;87:440-441.

19. Nieuwkamp DJ, Murk JL, Cremers CHP, et al. PML in a patient without severe lymphocytopenia receiving dimethyl fumarate. N Engl J Med 2015;372:1474-1476.

20. Mrowietz U, Asadullah K. Dimethylfumarate for psoriasis: more than a dietary curiosity. Trends Mol Med 2005;11: 43-48.

21. Lamoreaux L, Roederer M, Koup R. Intracellular cytokine optimization and standard operating procedure. Nat Protoc 2006;1:1507-1516.

22. Brown H, Prescott R. Repeated measures data. In: Applied Mixed Models in Medicine, 3rd ed. Hoboken, NJ: Wiley; 2015.

23. Sebok B, Mahrle G, Gollnick H, Bonnekoh B. Originalarbeiten-Dimethylfumarate is the Fumaderm (R)-compound with the strongest induction of apoptosis-phenomena in lympho-histiocytic U-937 cells. Zeitschrift fur Hautkrankheiten 2000;75:347-351.

24. Treumer F, Zhu K, Gläser R, Mrowietz U. Dimethylfumarate is a potent inducer of apoptosis in human T cells. J Invest Dermatol 2003;121:1383-1388.

25. Litjens NH, van Strijen E, van Gulpen C, et al. In vitro pharmacokinetics of anti-psoriatic fumaric acid esters. BMC Pharmacol 2004;4:22.
26. Ockenfels HM, Schultewolter T, Ockenfels G, Funk R, Goos $\mathrm{M}$. The antipsoriatic agent dimethylfumarate immunomodulates T-cell cytokine secretion and inhibits cytokines of the psoriatic cytokine network. Br J Dermatol 1998;139:390-395.

27. Peng H, Li H, Sheehy A, Cullen P, Allaire N, Scannevin $\mathrm{RH}$. Dimethyl fumarate alters microglia phenotype and protects neurons against proinflammatory toxic microenvironments. J Neuroimmunol 2016;299: $35-44$.

28. Rostami-Yazdi M, Clement B, Schmidt TJ, Schinor D, Mrowietz U. Detection of metabolites of fumaric acid esters in human urine: implications for their mode of action. J Invest Dermatol 2009;129:231-234.

29. Gupta S, Gollapudi S. Susceptibility of naive and subsets of memory T cells to apoptosis via multiple signaling pathways. Autoimmun Rev 2007;6:476-481.

30. Gupta S, Agrawal S, Gollapudi S. Differential effect of human herpesvirus $6 \mathrm{~A}$ on cell division and apoptosis among naive and central and effector memory CD4+ and CD8 + t-cell subsets. J Virol 2009;83:5442-5450.

31. Suzuki I, Fink PJ. The dual functions of Fas ligand in the regulation of peripheral CD8(+) and CD4(+) T cells. Proc Natl Acad Sci USA 2000;97:1707-1712.

32. Macallan DC, Wallace D, Zhang Y, et al. Rapid turnover of effector-memory CD4(+) T cells in healthy humans. J Exp Med 2004;200:255.

33. Helwa I, Patel R, Karempelis P, Kaddour-Djebbar I, Choudhary V, Bollag WB. The antipsoriatic agent monomethylfumarate has antiproliferative, prodifferentiative, and anti-inflammatory effects on keratinocytes. J Pharmacol Exp Ther 2014;352:90. 


\title{
Neurology \\ Neuroimmunology \& Neuroinflammation
}

\author{
Dimethyl fumarate-induced lymphopenia in MS due to differential T-cell subset \\ apoptosis \\ Mahtab Ghadiri, Ayman Rezk, Rui Li, et al. \\ Neurol Neuroimmunol Neuroinflamm 2017;4; \\ DOI 10.1212/NXI.0000000000000340
}

This information is current as of March 23, 2017

Neurol Neuroimmunol Neuroinflamm is an official journal of the American Academy of Neurology.

Published since April 2014, it is an open-access, online-only, continuous publication journal. Copyright

Copyright (C) 2017 The Author(s). Published by Wolters Kluwer Health, Inc. on behalf of the American

Academy of Neurology. All rights reserved. Online ISSN: 2332-7812.

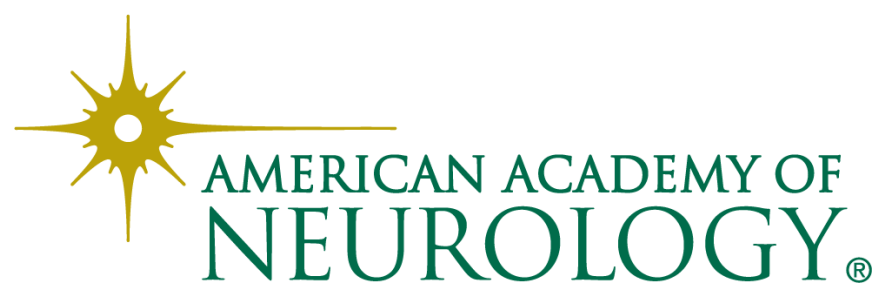




\section{Updated Information \& Services}

\section{Supplementary Material}

\section{References}

Citations

Subspecialty Collections

Permissions \& Licensing

Reprints including high resolution figures, can be found at: http://nn.neurology.org/content/4/3/e340.full.html

Supplementary material can be found at: http://nn.neurology.org/content/suppl/2017/03/23/4.3.e340.DC1

This article cites 32 articles, 5 of which you can access for free at: http://nn.neurology.org/content/4/3/e340.full.html\#\#ref-list-1

This article has been cited by 2 HighWire-hosted articles: http://nn.neurology.org/content/4/3/e340.full.html\#\#otherarticles

This article, along with others on similar topics, appears in the following collection(s):

\section{All Immunology}

http://nn.neurology.org//cgi/collection/all_immunology

Multiple sclerosis

http://nn.neurology.org//cgi/collection/multiple_sclerosis

Information about reproducing this article in parts (figures,tables) or in its entirety can be found online at:

http://nn.neurology.org/misc/about.xhtml\#permissions

Information about ordering reprints can be found online: http://nn.neurology.org/misc/addir.xhtml\#reprintsus

Neurol Neuroimmunol Neuroinflamm is an official journal of the American Academy of Neurology.

Published since April 2014, it is an open-access, online-only, continuous publication journal. Copyright

Copyright $\odot 2017$ The Author(s). Published by Wolters Kluwer Health, Inc. on behalf of the American Academy of Neurology. All rights reserved. Online ISSN: 2332-7812.

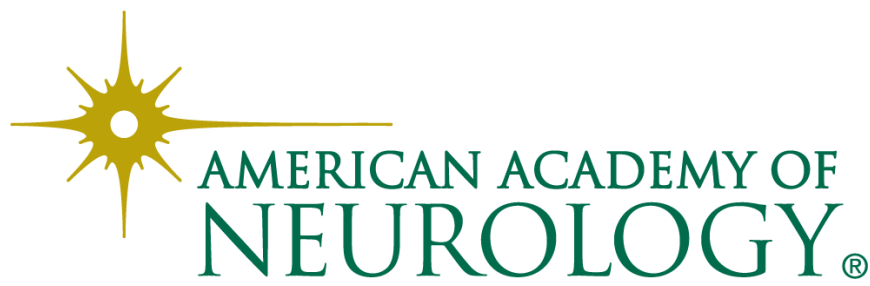

